\title{
Isolation and Characterization of Two New Antimicrobial Acids from Quercus incana (Bluejack Oak)
}

\author{
Rizwana Sarwar $\mathbb{D}^{1},{ }^{1}$ Umar Farooq $\mathbb{D}^{1},{ }^{1}$ Sadia Naz, ${ }^{1}$ Nadia Riaz $\mathbb{D},{ }^{2}$ Syed Majid Bukhari, \\ Abdur Rauf $\mathbb{D}^{\mathbb{D}}{ }^{3}$ Yahia N. Mabkhot $\mathbb{D}^{4},{ }^{4}$ and Salim S. Al-Showiman ${ }^{4}$ \\ ${ }^{1}$ Department of Chemistry, COMSATS Institute of Information Technology, Abbotabad 22060, Pakistan \\ ${ }^{2}$ Department of Environmental Sciences, COMSATS Institute of Information Technology, Abbotabad 22060, Pakistan \\ ${ }^{3}$ Department of Chemistry, University of Swabi, Anbar, Khyber Pakhtunkhwa 23430, Pakistan \\ ${ }^{4}$ Department of Chemistry, College of Science, King Saud University, P.O. Box 2455, Riyadh 1451, Saudi Arabia
}

Correspondence should be addressed to Umar Farooq; umarf@ciit.net.pk, Abdur Rauf; mashaljcs@yahoo.com, and Yahia N. Mabkhot; yahia@ksu.edu.sa

Received 24 August 2017; Accepted 27 November 2017; Published 28 January 2018

Academic Editor: Nikos Chorianopoulos

Copyright (C) 2018 Rizwana Sarwar et al. This is an open access article distributed under the Creative Commons Attribution License, which permits unrestricted use, distribution, and reproduction in any medium, provided the original work is properly cited.

Two new compounds [1-2] were purified from ethyl acetate fraction of Quercus incana. The structure of these compounds is mainly established by using advanced spectroscopic technique such as UV, IR, one-dimensional (ID) and two-dimensional (2D) NMR techniques, and EI mass. The structural formula was deduced to be 4-hydroxydecanoic acid [1] and 4-hydroxy-3-(hydroxymethyl) pentanoic acid [2]. Both isolated compounds were tested for their antimicrobial potential and showed promising antifungal activity against Aspergillus niger and Aspergillus flavus.

\section{Introduction}

The family Fagaceae is large family comprising 8 genera and about $800-1100$ species. Quercus is the largest genus of family Fagaceae having huge medicinal importance and mostly found in dry conditions [1]. The genus Quercus have long been considered among the clades of woody angiosperms in terms of species diversity, horticultural merit, ecological dominance, and industrial and economic values [2]. The Quercus robur is the only cultivated species while other 600 known species are found in temperate regions of the Northern Hemisphere, Southward through Central America to Colombia and through Turkey to Pakistan [3].

The wood is durable, is attractively grained, and is mostly utilized for timber purposes; it is particularly important in shipbuilding, construction for flooring, furniture, railroad ties, and veneers. The bark of Quercus spp. has been used for medicinal purposes and is an important source of phenolic compounds like tannins which are used for tanning leather and wine production [4]. The fruit (acorn) of Quercus has husk coating which is edible and highly nutritious and rich in carbohydrates and protein. Quercus (oak) species are utilized in conventional pharmaceutical, as astringent, antiseptic, and hemostatic and in addition to the treatment of acute diarrhea, hemorrhoid, and oral, genital, and anal mucosa inflammation. Moreover, the decoction plants from this genus can be used against burns and added to ointments for the healing of cuts [5]. Oak seeds are a major source of sugar, amino acids, lipids, and different sterols [6]. Quercus species have been utilized against problems of skin, wounds and gastrointestinal illnesses [7], astringent, mellow germfree, small cuts [8], and mouth washes [9] all suggesting their antimicrobial potential.

Genus Quercus is characterized by six species found mostly in Northern areas of Pakistan. The most promising timber specie is Quercus incana Roxb. (Blue jack oak or cinnamon oak) locally called Ban shindar, Kharpata serci (Punjabi), Rein (Hindko), and Serie (Pushto) [10]. The Q. incana has huge medicinal usage; it may be used as astringent [11], diuretic, and antidiarrheal agent and for treatment of asthma. Bark and leaves of Q. incana may be used as antipyretic, antirheumatism, antidiabetic, and antiarthritic 


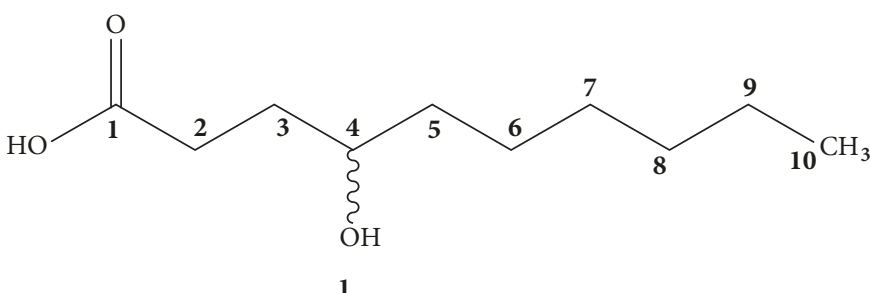

1

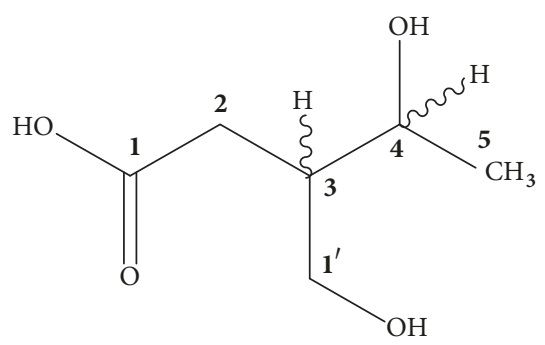

2

FIGURE 1: Structure of compounds [1-2].

purposes [12]. These medical applications and therapeutic potential of Quercus incana prompted us to carry out the phytochemical investigation to explore biologically active compounds.

\section{Material and Methods}

2.1. Experimental Procedures. The ethyl acetate soluble fraction was selected for isolation of bioactive compounds using column chromatographic analysis having column silica and flash silica gel as an adsorbent material. The column was eluted by using $n$-hexane and ethyl acetate with increasing polarity, which yield two new compounds 4-hydroxy decanoic acid [1] and 4-hydroxy-3-(hydroxymethyl) pentanoic acid [2] by increasing polarity. The purity of compounds [1-2] was checked by using precoated TLC plates. The IR spectrum was recorded by using spectrophotometer JASCO-320A. The EI mass was recoded on double focusing Varian MAT-312 Spectrometer. ${ }^{1} \mathrm{H}-\mathrm{NMR}$ and ${ }^{13} \mathrm{C}-\mathrm{NMR}$ spectra were measured by using advance Bruker AMX300 spectrometer machine. The chemical shifts in parts per million $(\delta)$ relative to tetramethylsilane as an internal standard and scalar $(J)$ were described in $\mathrm{Hz}$.

2.2. Plant Extraction and Fractionation. Extraction and fractionation of Quercus incana were reported in our previous study [13]. Ethyl acetate soluble fraction was subjected to repeated column chromatography which yielded two pure compounds [1-2].

2.3. Antibacterial Activity of Compounds [1-2]. Antibacterial activity was performed by agar well diffusion method with some modifications [14]. Three Gram-positive (Staphylococcus aureus, Micrococcus luteus, and Bacillus subtilis) and Gram-negative (Escherichia coli, Pseudomonas pickettii, and Shigella flexneri) pathogens were used in study. $10 \mu \mathrm{g}$ of each compounds [1-2] was dissolved in $1 \mathrm{~mL}$ DMSO. Standard drug and each sample $(20 \mu \mathrm{L})$ were poured in $6 \mathrm{~mm}$ well. The assay plates were incubated at $37^{\circ} \mathrm{C}$ for $24 \mathrm{hrs}$. The zone of inhibition was dignified in $\mathrm{mm}$ and DMSO was used as a negative control in the experiment.

2.4. Antifungal Assay. Disc diffusion methods were used for determination of antifungal effects by using two selected fungal strains such as Aspergillus niger and Aspergillus flavus [15].
DMSO was used as a solvent; before applying compounds on petri plates DMSO was completely evaporated.

Characterization of Compound 1. Colorless oil; IR (KBr) $v_{\max }$ 3622 br $(\mathrm{OH}), 1714(\mathrm{C}=\mathrm{O}) \mathrm{cm}^{-1} \cdot[\alpha]_{\mathrm{D}}{ }^{25}+34.80^{\circ}(c=0.78$, $\mathrm{CHCl}_{3}$ ). EI-MS m/z: (rel. int.) $188[\mathrm{M}]^{+}$(15), 176 (9), 157 (35), 128 (5), 115 (9). HR-EI-MS: $m / z$ 188. 1420 (calcd. for 188.1412 for $\left.\mathrm{C}_{10} \mathrm{H}_{20} \mathrm{O}_{3}\right) .{ }^{1} \mathrm{H}-\mathrm{NMR}\left(\mathrm{CDCl}_{3}, 300 \mathrm{MHz}\right): \delta 3.62(1 \mathrm{H}, \mathrm{m}$, $\mathrm{H}-4), 0.88$ (3H, t, $J=7.7 \mathrm{~Hz}, \mathrm{H}-10), 2.08$ (2H, m, H-2), 1.49, 1.62 (2H, m, H-3), 1.45 (2H, m, H-5), 1.47, 1.33 (2H, m, H-6), 1.30 (2H, m, H-7), 1.28 (2H, m, H-8), 1.29 (2H, m, H-9). ${ }^{13} \mathrm{C}-$ $\mathrm{NMR}\left(\mathrm{CDCl}_{3}, 75 \mathrm{MHz}\right): \delta 179.6$ (C-1), 72.1 (C-4), 13.9 (C-10), 34.6 (C-2), 34.9 (C-3), 37.9 (C-5), 26.1 (C-6), 29.8 (C-7), 32.0 (C-8), 22.1 (C-9).

Characterization of Compound 2. Colorless oil: IR $(\mathrm{KBr}) v_{\max }$ $3495(\mathrm{OH}), 1708(\mathrm{C}=\mathrm{O}) \mathrm{cm}^{-1} \cdot[\alpha]_{\mathrm{D}}{ }^{25}+53.60^{\circ}(c=0.97$, $\mathrm{CHCl}_{3}$ ). EI-MS m/z: (rel. int.\%) $131[\mathrm{M}-\mathrm{OH}]^{+} 131$ (10), 115 (8), 86 (100), 71 (31). HR-EI-MS: $m / z$ [M-OH] ${ }^{+} 131.0744$ (calcd. 131.0736 for $\left.\mathrm{C}_{6} \mathrm{H}_{11} \mathrm{O}_{3}-\mathrm{OH}\right) .{ }^{1} \mathrm{H}-\mathrm{NMR}\left(\mathrm{CDCl}_{3}, 300 \mathrm{MHz}\right): \delta$ 2.35 (1H, m, H-2), 2.04 (1H, m, H-2), 2.58 (1H, m, H-3), 3.92 $(1 \mathrm{H}, \mathrm{m}, \mathrm{H}-4), 1.23(3 \mathrm{H}, \mathrm{d}, J=6.9 \mathrm{~Hz}, \mathrm{H}-5), 4.31(2 \mathrm{H}, \mathrm{m}, \mathrm{H}-$ $\left.1^{\prime}\right) .{ }^{13} \mathrm{C}-\mathrm{NMR}\left(\mathrm{CDCl}_{3}, 75 \mathrm{MHz}\right): \delta 177.5(\mathrm{C}-1), 27.3$ (C-2), 45.9 (C-3), 68.1 (C-4), 20.9 (C-5), $65.5\left(\mathrm{C}-1^{\prime}\right)$.

\section{Result and Discussion}

Ethyl acetate soluble fraction was subjected to repeated column chromatography on silica gel using $n$-hexane and ethyl acetate as a solvent with gradual increasing in polarity up to $100 \%$ ethyl acetate, which resulted in four subfractions (Fractions A-D). The fractions obtained based on TLC profile were resubjected to pencil column chromatography and eluted with $n$-hexane:EtOAc, $25: 75$ and $n$-hexane: EtOAc, $30: 70$ to purify compound $\mathbf{1}(10.5 \mathrm{mg})$ and compound 2 (9.8 mg) (Figure 1).

Compound 1 was isolated as a colorless oil and has molecular formula of $\mathrm{C}_{10} \mathrm{H}_{20} \mathrm{O}_{3}$ as suggested by molecular ion peak at $m / z 188[\mathrm{M}]^{+}$in HR-EIMS. The other fragment peaks were obtained at $m / z 176,157,128$, and 115 . The HREIMS gave exact mass of compound 1 which was at $m / z$ 188.1420 (calcd. $m / z$ 188.1412). The IR spectrum displayed absorption bands for hydroxyl and carbonyl groups at 3622 and $1714 \mathrm{~cm}^{-1}$, respectively. The ${ }^{1} \mathrm{H}-\mathrm{NMR}$ spectrum of compound 1 exhibited typical signal for aliphatic acid skeleton, which was strongly supported by DEPT experiment. The 
TABLE 1: ${ }^{1} \mathrm{H}-\mathrm{NMR}\left(\mathrm{CDCl}_{3}, 300 \mathrm{MHz}\right)$ data of compounds [1-2] in ppm, $J$ in $\mathrm{Hz}$.

\begin{tabular}{lcc}
\hline Position & $\mathbf{1}$ & $\mathbf{2}$ \\
\hline 1 & - & - \\
2 & $2.08, \mathrm{~m}$ & $2.04, \mathrm{~m}$ \\
& $1.62, \mathrm{~m}$ & $2.35, \mathrm{~m}$ \\
3 & $1.49, \mathrm{~m}$ & $2.58, \mathrm{~m}$ \\
4 & $3.62, \mathrm{~m}$ & $3.92, \mathrm{~m}$ \\
5 & $1.45, \mathrm{~m}$ & - \\
6 & $1.47, \mathrm{~m}$ & - \\
7 & $1.33, \mathrm{~m}$ & - \\
8 & $1.30, \mathrm{~m}$ & - \\
9 & $1.28, \mathrm{~m}$ & - \\
10 & $1.29, \mathrm{~m}$ & \\
$1^{\prime}$ & $0.88(\mathrm{t}, J=7.7)$ & $4.31, \mathrm{~m}$ \\
\hline
\end{tabular}

${ }^{13} \mathrm{C}$-NMR spectrum revealed the presence of one methyl, one methine, seven methylene, and one quaternary carbon signals. The methine signal appearing at $\delta_{\mathrm{H}} 3.62(1 \mathrm{H}, \mathrm{m})$ was assigned to $\mathrm{H}-4$ while methyl group resonated at $\delta_{\mathrm{H}} 0.88$ $(3 \mathrm{H}, \mathrm{t}, J=7.7 \mathrm{~Hz})$. Typical methylene signals were resonated as multiplet for seven methylene carbons at $\delta_{\mathrm{H}} 2.08(2 \mathrm{H}$, $\mathrm{m}), \delta_{\mathrm{H}} 1.49(1 \mathrm{H}, \mathrm{m}), \delta_{\mathrm{H}} 1.45(2 \mathrm{H}, \mathrm{m}), \delta_{\mathrm{H}} 1.33(1 \mathrm{H}, \mathrm{m}), \delta_{\mathrm{H}}$ $1.47(1 \mathrm{H}, \mathrm{m}), \delta_{\mathrm{H}} 1.30(2 \mathrm{H}, \mathrm{m}), \delta_{\mathrm{H}} 1.28(2 \mathrm{H}, \mathrm{m})$, and $\delta_{\mathrm{H}}$ $1.29(2 \mathrm{H}, \mathrm{m})$ assigned to $\mathrm{H}-2, \mathrm{H}-3, \mathrm{H}-5, \mathrm{H}-6, \mathrm{H}-7, \mathrm{H}-8$, and $\mathrm{H}-9$, respectively (Table 1 ). The ${ }^{13} \mathrm{C}-\mathrm{NMR}$ spectrum (BB and DEPT) corroborated the presence of seven methylene carbons, one methine carbon, one terminal methyl carbon, and one quaternary carbon. The carbonyl carbon showed signals at $\delta_{\mathrm{C}} 179.6$ whereas methine signal centered at $\delta_{\mathrm{C}} 72.1$. The ${ }^{13} \mathrm{C}$-NMR chemical shift of $\mathrm{CH}_{3}$-C10 was observed at $\delta_{\mathrm{C}} 13.9$ and seven methylene carbons appeared at $\delta_{\mathrm{C}} 34.6$, $34.9,37.9,26.1,29.8,32.0$, and 22.1 for C-2, C-3, C-5, C-6, C-7, $\mathrm{C}-8$, and C-9, respectively (Table 2). The HMBC and COSY spectra were quite helpful for accurate placement of various substituents in the molecule. The HMBC spectrum showed strong correlation of methine proton at $\delta_{\mathrm{H}} 3.62(\mathrm{H}-4)$ with C-2, C-3, C-5, and C-6 [13]. The methyl proton at $\delta_{\mathrm{H}} 0.88$ showed strong HMBC correlation with C-9 $\left(\delta_{\mathrm{C}} 22.1\right), \mathrm{C}-8$ $\left(\delta_{\mathrm{C}} 32.0\right)$ which was quite supportive in the establishment of structure. Finally all spectral data confirmed, compound 1 as an aliphatic acid having straight chain of $-\left(\mathrm{CH}_{2}\right)_{7}-\mathrm{CH}_{3}$ moiety [16] and was proposed to be 4-hydroxy decanoic acid.

Compound 2 was isolated as colorless oil. Its structure was mainly established by ${ }^{1} \mathrm{H}-\mathrm{NMR}$ and high resolution mass spectroscopy and supported by ${ }^{13} \mathrm{C}$-NMR spectrum. Its molecular formula $\mathrm{C}_{6} \mathrm{H}_{12} \mathrm{O}_{4}$ was concluded from the accurate mass measurement of peak at $m / z[\mathrm{M}-\mathrm{OH}]^{+} 131$, corresponding to molecular composition $\mathrm{C}_{6} \mathrm{H}_{11} \mathrm{O}_{3}-\mathrm{OH}$. In addition to its molecular ion peak, it showed some characteristic fragments at $m / z 115,86$, and 71 . The HR-EIMS gave exact mass of compound 2 at $m / z 131.0744$ (calcd. 131.0736 for $\mathrm{C}_{6} \mathrm{H}_{11} \mathrm{O}_{3}-\mathrm{OH}$ ). The IR spectrum showed absorption bands at
TABLE 2: ${ }^{13} \mathrm{C}-\mathrm{NMR}\left(\mathrm{CDCl}_{3}, 75 \mathrm{MHz}\right)$ of compounds [1-2] in ppm.

\begin{tabular}{lcc}
\hline Position & $\mathbf{1}$ & $\mathbf{2}$ \\
\hline 1 & 179.6 & 177.5 \\
2 & 34.6 & 27.3 \\
3 & 34.9 & 45.9 \\
4 & 72.1 & 68.1 \\
5 & 37.9 & 20.9 \\
6 & 26.1 & - \\
7 & 29.8 & - \\
8 & 32.0 & - \\
9 & 22.1 & - \\
10 & 13.9 & - \\
$1^{\prime}$ & - & 65.5 \\
\hline
\end{tabular}

$3495 \mathrm{~cm}^{-1}$ and $1708 \mathrm{~cm}^{-1}$ indicating presence of the hydroxyl group and carbonyl carbon, respectively. Similarly, broad absorption centered at $2935 \mathrm{~cm}^{-1}$ suggested the presence of carboxylic acid. The ${ }^{1} \mathrm{H}$-NMR showed a signal for a secondary methyl group at $\delta 1.23(3 \mathrm{H}, \mathrm{d}, J=6.9 \mathrm{~Hz}, \mathrm{H}-5)$, connected to a methine group resonated at $\delta_{\mathrm{H}} 3.92(1 \mathrm{H}, \mathrm{m}, \mathrm{H}-$ 4) possessing hydroxyl group, while the other methine signal appeared at $\delta_{\mathrm{H}} 2.58(1 \mathrm{H}, \mathrm{m}, \mathrm{H}-3)$. The downfield methylene bearing hydroxyl group appeared at $\delta_{\mathrm{H}} 4.31\left(2 \mathrm{H}, \mathrm{m}, \mathrm{H}-1^{\prime}\right)$ and the other methylene centered at $\delta_{\mathrm{H}} 2.04(1 \mathrm{H}, \mathrm{m}, \mathrm{H}-2)$ and $\delta_{\mathrm{H}}$ $2.35(1 \mathrm{H}, \mathrm{m}, \mathrm{H}-2)$ was directly connected to carboxylic acid (Table 1). The ${ }^{13} \mathrm{C}$-NMR spectrum confirmed the presence of one methyl carbon, two methylene groups, two methine carbons, and one quaternary carbon in the structure.

In ${ }^{13} \mathrm{C}-\mathrm{NMR}$ spectrum, signal for secondary methyl appeared at $\delta_{\mathrm{C}} 20.9$ whereas the methine signal bearing hydroxyl group was observed at $\delta_{\mathrm{C}} 68.1$ for C-4. The signal for another methine appeared at $\delta_{\mathrm{C}} 45.9$ for C-3. The side chain methylene having free hydroxyl group resonated at $\delta_{\mathrm{C}} 65.5$, while the second methylene group at position C-2 appeared at $\delta_{\mathrm{C}} 27.3$. Similarly, the quaternary carbon in the form of carboxylic acid showed signal at $\delta_{\mathrm{C}} 177.5$ (Table 2). Based on the HMBC and H-H COSY correlation (Figure 2), the connectivity of the C-1 to C-5 chain was found in agreement with literature [17]. The HMBC spectrum showed $\mathrm{H}-\mathrm{C}$ correlation of $\mathrm{CH}_{3}-5$ with that of C-4 and C-3. Similarly the position of hydroxyl group at $\mathrm{C}^{\prime} 1^{\prime}$ was confirmed by strong $\mathrm{HMBC}$ correlation of $\mathrm{CH}_{2}-1^{\prime}$ with $\mathrm{C}-3, \mathrm{C}-2$, and $\mathrm{C}-$ 4 and weak interaction with $\mathrm{C}-1$. The structure of compound 2 was mainly established by ${ }^{1} \mathrm{H}-\mathrm{NMR}$, high resolution mass spectrometry and supported by ${ }^{13} \mathrm{C}-\mathrm{NMR}$ spectrum. From all spectral data it was evident that compound 2 was 4 -hydroxy3-(hydroxymethyl) pentanoic acid.

3.1. Antibacterial Activity. The antibacterial activity of isolated compounds [1-2] was determined by agar well diffusion method (Table 3). Compound $\mathbf{1}$ was significantly active against Bacillus subtilis, Staphylococcus aureus, and Micrococcus luteus (Gram-positive). Both compounds [1-2] showed promising antibacterial activity against Staphylococcus aureus with $16 \mathrm{~mm}$ and $13 \mathrm{~mm}$ zone of inhibition. Compound 2 was 


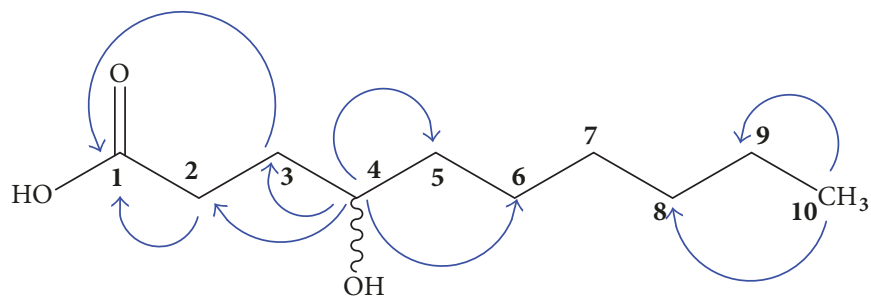

Important $\mathrm{HMBC}$ correlation of $\mathbf{1}$

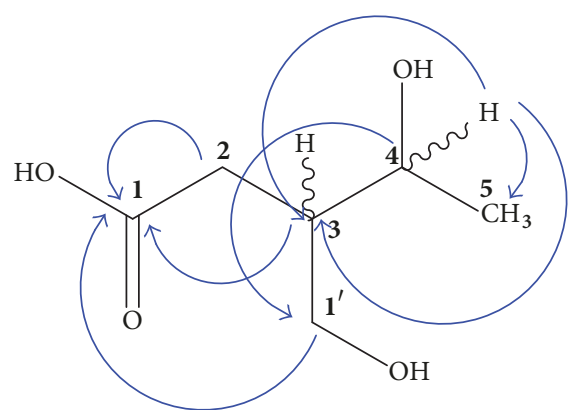

Important HMBC correlation of $\mathbf{2}$

FIgURE 2: HMBC correlation of compounds [1-2].

TABLE 3: Antibacterial activity of isolated compounds [1-2].

\begin{tabular}{lcccc}
\hline S. number & Culture & \multicolumn{2}{c}{ Zone of inhibition $(\mathrm{mm})$} \\
& & $\mathbf{1}$ & $\mathbf{2}$ & Ciprofloxacin \\
\hline 1 & Bacillus subtilis & 8 & 5 & 8 \\
2 & Staphylococcus aureus & 16 & 13 & 16 \\
3 & Micrococcus luteus & 11 & 9 & 18 \\
4 & Pseudomonas pickettii & 0 & 0 & 0 \\
5 & Escherichia coli & 0 & 0 & 0 \\
6 & Shigella flexneri & 6 & 9 & 14 \\
\hline
\end{tabular}

TABLE 4: Antifungal activity of isolated compounds [1-2].

\begin{tabular}{lcc}
\hline \multirow{2}{*}{ Extract } & \multicolumn{2}{c}{ Pathogenic fungi } \\
& Aspergillus flavus & Aspergillus niger \\
\hline 1 & $12 \mathrm{~mm} \pm 0.50$ & $15 \mathrm{~mm} \pm 0.70$ \\
2 & $17 \mathrm{~mm} \pm 0.28$ & $22 \mathrm{~mm} \pm 0.57$ \\
Nystatin (standard) & $16 \mathrm{~mm} \pm 0.92$ & $21 \mathrm{~mm} \pm 0.28$ \\
\hline
\end{tabular}

Note. Each value in the table was obtained by calculating the average of three experiments.

moderately active against Bacillus subtilis and Micrococcus luteus with $5 \mathrm{~mm}$ and $9 \mathrm{~mm}$ zone of inhibition. Both compounds were inactive against Escherichia coli and Shigella flexneri.

3.2. Antifungal Activity. Antifungal activity of both compounds [1-2] was done against Aspergillus flavus and Aspergillus niger. Both compounds [1-2] showed immense activity against Aspergillus niger with $15 \mathrm{~mm} \pm 0.70$ and $22 \mathrm{~mm} \pm 0.57$ zone of inhibition (Table 4 ). Moderate activity was observed by compound 1 against Aspergillus flavus having $12 \mathrm{~mm} \pm 0.50$ zone of inhibition.

\section{Conclusion}

The current study describes the isolation, characterization, and antimicrobial activity of isolated compounds from ethyl acetate fraction of Quercus incana. Both compounds displayed promising antimicrobial activity against human bacterial and fungal strains. Therefore, these isolated compounds may be considered as the lead compounds as an antimicrobial agents.

\section{Conflicts of Interest}

There are no conflicts of interest regarding this paper.

\section{Acknowledgments}

The authors extend their appreciation to the Deanship of Scientific Research at King Saud University for its funding this prolific research group no. RGP-007.

\section{References}

[1] K. C. Nixon and W. L. Crepet, "Trigonobalanus (Fagaceae): Taxonomic Status and Phylogenetic Relationships," American Journal of Botany, vol. 76, no. 6, p. 828, 1989.

[2] M. Kappelle, "Neotropical montane oak forests: overview and outlook," in Ecology and Conservation of Neotropical Montane Oak Forests, pp. 449-467, Springer, 2006.

[3] E. Nisar and S. I. Ali, Flora of West Pakistan, Botany Department, Gordon College, Rawalpindi, Pakistan, 1976.

[4] S. T. Shah, H. Ahmad, and R. Zamir, "Pollen morphology of three species of Quercus (Family Fagaceae," Journal of Agriculture, Forestry and the Social Sciences, vol. 1, no. 4, pp. 359360, 2005.

[5] L. Bremness, Herbs (Handbooks), Dorling Kindersley Publishers LTD, London, UK, 1994.

[6] S. Rakić, S. Petrović, J. Kukić et al., "Influence of thermal treatment on phenolic compounds and antioxidant properties 
of oak acorns from Serbia," Food Chemistry, vol. 104, no. 2, pp. 830-834, 2007.

[7] L. Viegi, A. Pieroni, P. M. Guarrera, and R. Vangelisti, "A review of plants used in folk veterinary medicine in Italy as basis for a databank," Journal of Ethnopharmacology, vol. 89, no. 2-3, pp. 221-244, 2003.

[8] M. L. Leporatti and S. Ivancheva, "Preliminary comparative analysis of medicinal plants used in the traditional medicine of Bulgaria and Italy," Journal of Ethnopharmacology, vol. 87, no. 2-3, pp. 123-142, 2003.

[9] T. Aburjai, M. Hudaib, R. Tayyem, M. Yousef, and M. Qishawi, "Ethnopharmacological survey of medicinal herbs in Jordan, the Ajloun Heights region," Journal of Ethnopharmacology, vol. 110, no. 2, pp. 294-304, 2007.

[10] M. Hussain and A. Ghani, "Herbal remidies used for gastrointestinal disorders in Kaghan valley," Pakistan Journal of Weed Science Research in SearchWorks, vol. 14, no. 3-4, pp. 169-200, 2008.

[11] F. Haq, H. Ahmad, and M. Alam, "Traditional uses of medicinal plants of Nandiar Khuwarr catchment (District Battagram), Pakistan," Journal of Medicinal Plants Research, vol. 5, no. 1, pp. 39-48, 2011.

[12] M. I. Shinwari and M. A. Khan, "Folk use of medicinal herbs of margalla hills National Park, Islamabad ," Journal of Ethnopharmacology, vol. 69, no. 1, pp. 45-56, 2000.

[13] R. Sarwar, U. Farooq, A. Khan et al., "Evaluation of antioxidant, free radical scavenging, and antimicrobial activity of Quercus incana Roxb.," Frontiers in Pharmacology, vol. 6, article no. 277, 2015.

[14] J. Harit, A. Barapatre, M. Prajapati, K. R. Aadil, and S. Senapati, "Antimicrobial activity of rhizome of selected Curcuma variety," International Journal of Life Sciences Biotechnology and Pharma Research, vol. 2, pp. 183-189, 2013.

[15] V. Bobbarala, V. R. Vadlapudi, and C. Naidu, "Antimicrobial potentialities of mangrove plant Avicennia marina," Journal of Pharmacy Research, vol. 2, no. 6, 2009.

[16] T. N. Misra, R. S. Singh, J. Upadhyay, and R. Srivastava, "Isolation of a natural sterol and an aliphatic acid from Vernonia cinerea," Phytochemistry, vol. 23, no. 2, pp. 415-417, 1984.

[17] K. Krohn, U. Farooq, U. Flörke et al., "Secondary metabolites isolated from an endophytic Phoma sp. - Absolute configuration of tetrahydropyrenophorol using the solid-state TDDFT CD methodology," European Journal of Organic Chemistry, no. 19, pp. 3206-3211, 2007. 


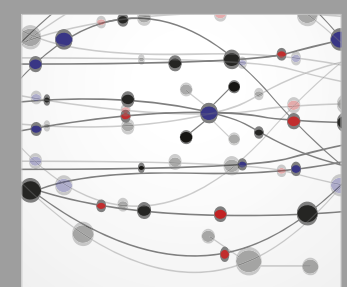

The Scientific World Journal
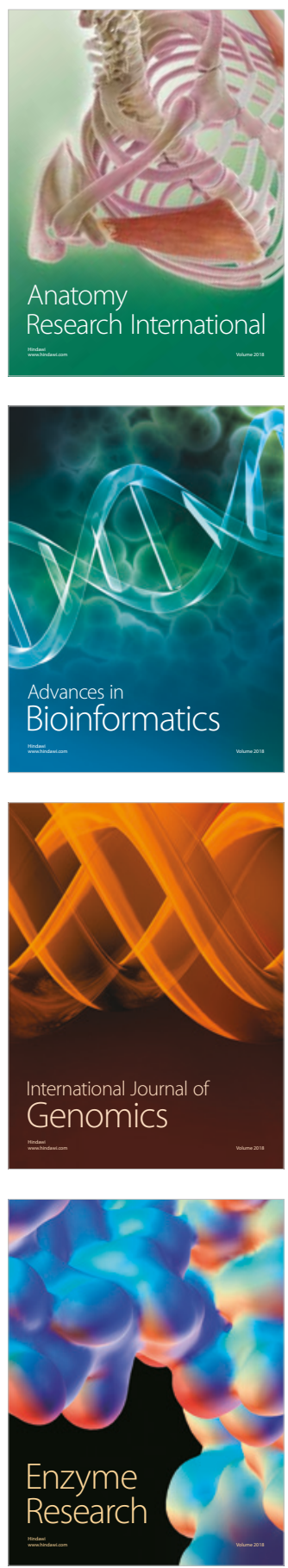
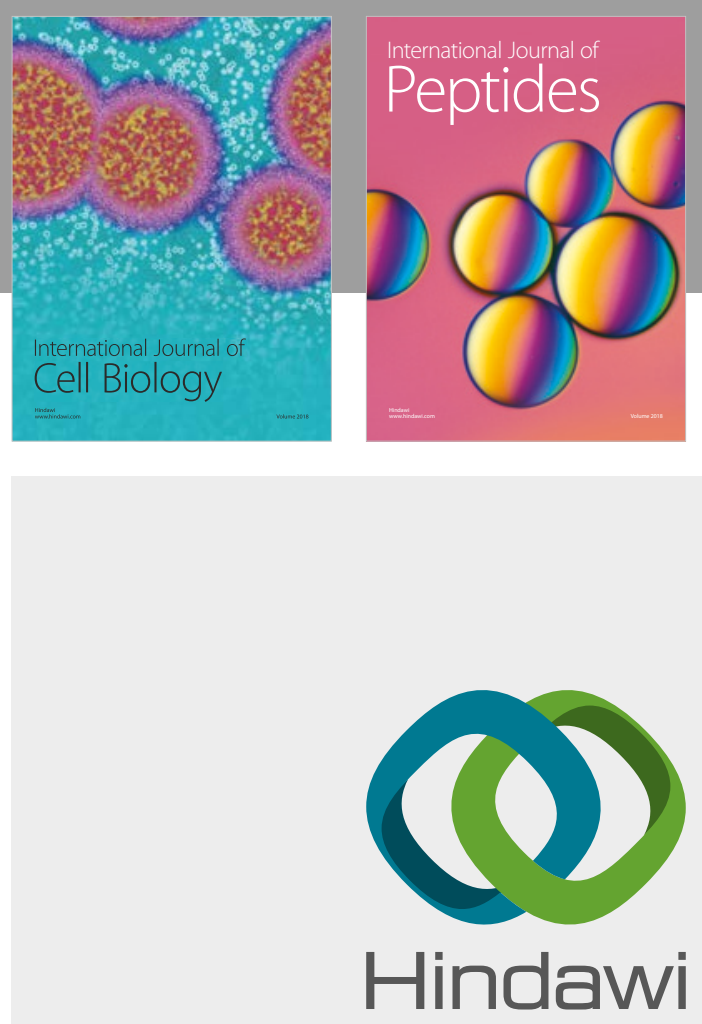

Submit your manuscripts at

www.hindawi.com
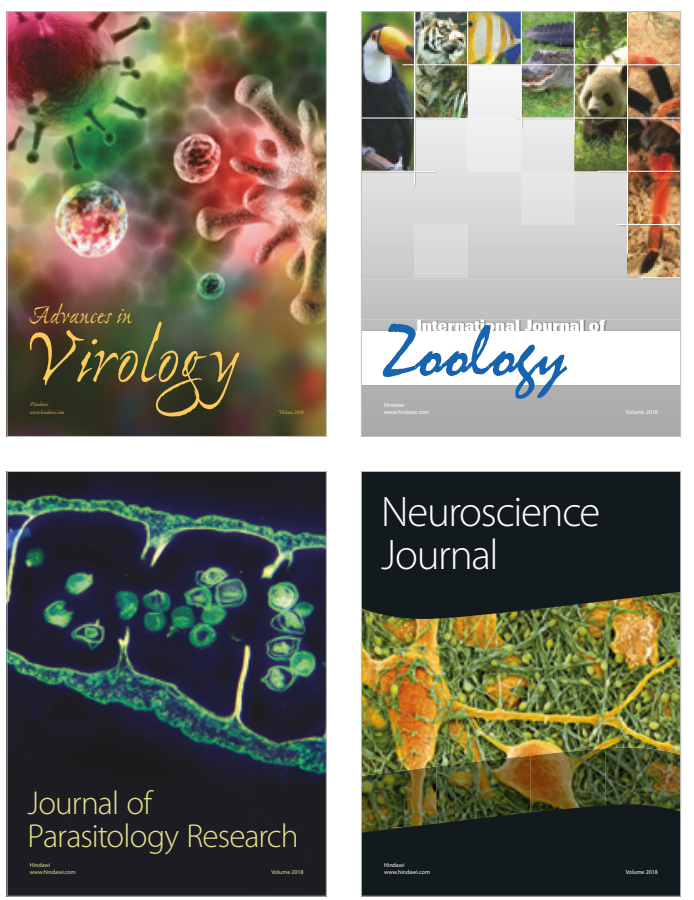
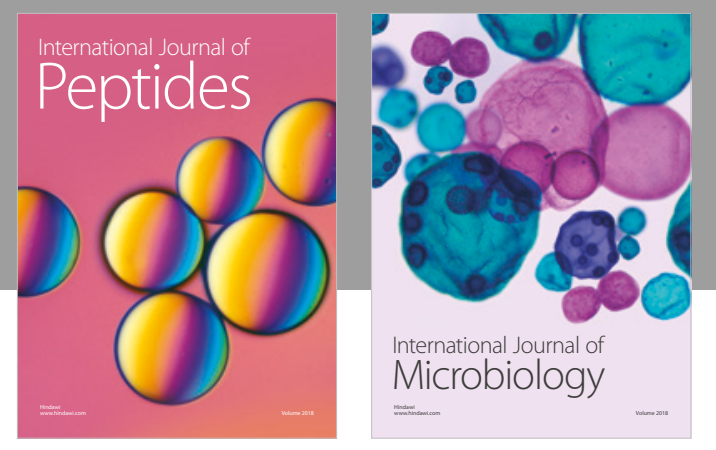

nternational Journal of Microbiology
Journal of
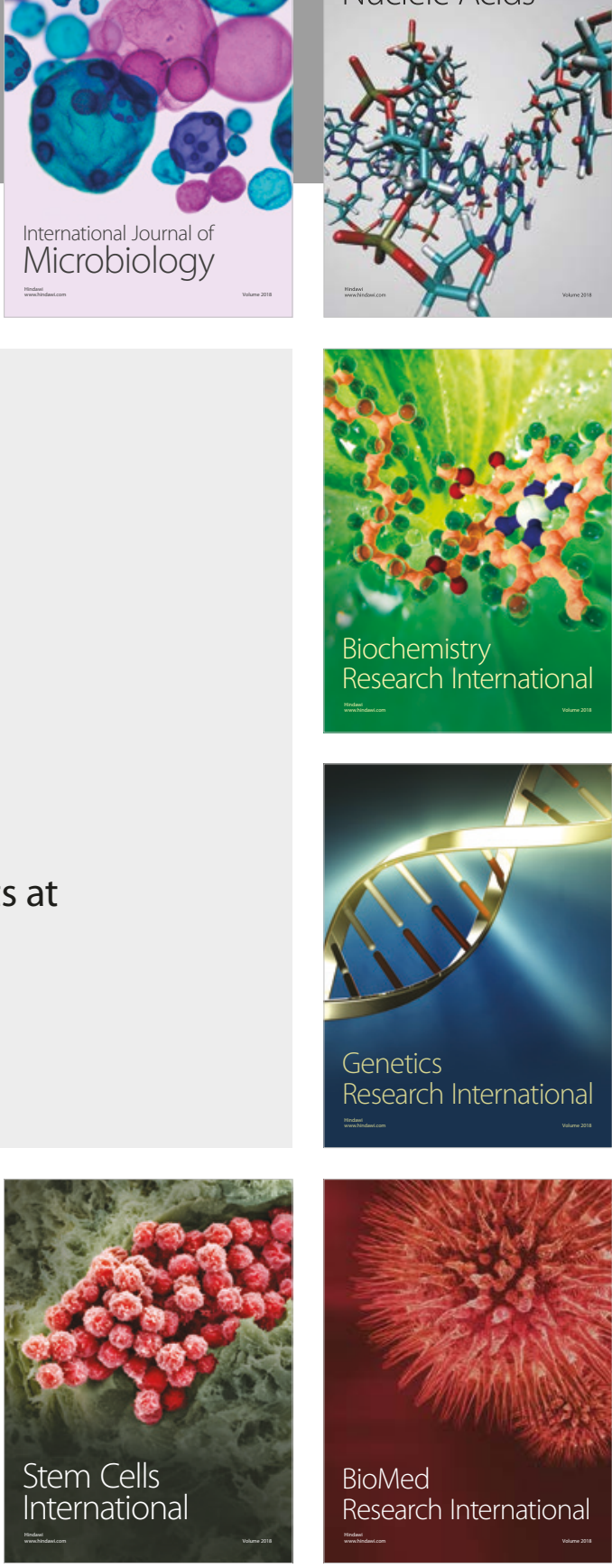
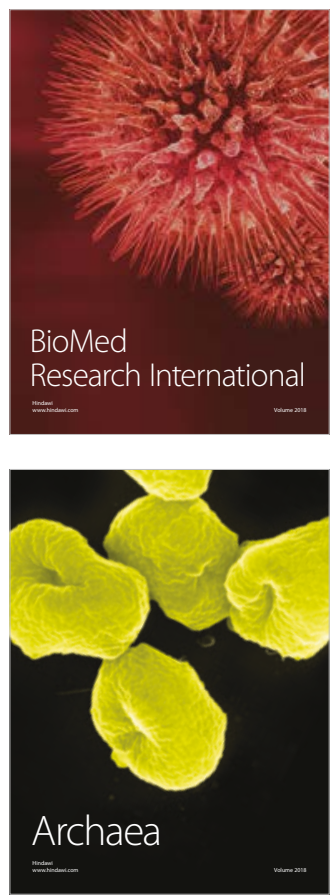